\title{
Total kalça artroplastisinde eklemleşme seçenekleri: Eklemleşme kime, hangi ikili?
}

\section{Bearing surface alternatives in total hip replacement: Which pair to whom?}

\author{
Hakan Kocaoğlu, Kerem Başarır, Bülent Erdemli
}

Ankara Üniversitesi Tıp Fakültesi, Ortopedi ve Travmatoloji Anabilim Dalı, Ankara

\begin{abstract}
1950'li yıllarda ilk kullanılışlarından beri total kalça replasmanında kullanılan implantlar çok gelişme göstermiştir. Cerrahi sonrası görülen en önemli sorunlar, implant yetmezliği, aseptik gevşeme ve protez enfeksiyonu olup, implant tribolojisi bu sorunları gidermek yönünde evrilmiştir. Günümüzde değişik üreticilerin hizmete sunduğu çok sayıda seçenek bulunmaktadır. Her bir yüzey seçeneğinin güçlü yanları olduğu gibi zayıf yönleri de vardır. Genel olarak bakıldığında yüzeyler sert ve yumuşak olmak üzere iki ana grupta toplanabilir. Metal, oksinyum ve seramik sert yüzeylere karşılık, polietilen ve türevlerinden oluşan yumuşak yüzeyler bulunmaktadır. Hastanın fizyolojik durumu, beklentileri, aktivite düzeyi, altta yatan patoloji ve cerrahın tercihleri yüzey seçimini belirleyen değişkenlerdir.
\end{abstract}

Günümüzde halen altın standart haline gelmiş ya da tüm hastalar için üstünlüğü kanıtlanmış bir yüzey eşleşmesi bulunmamaktadır. Bu yüzden, artroplasti ile ilgilenen cerrahın, kullanacağı seçeneklerin artı ve eksilerini bilmesi çok önemlidir.

Anahtar sözcülkler: total kalça replasmanı; artroplasti; yüzey özellikleri; kalça eklemi; polietilenler; metaller; seramikler; UHMWPE

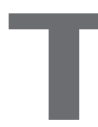
otal kalça artroplastisinde ideal eklem yüzünü oluşturacak materyaller için arayış, bu yöntemin ortaya atıldığı ilk anda başlamıştır. John Charnley'in total kalça artroplastisi için ilk yüzey tercihi olan teflon-paslanmaz çelik kısa sürede başarısız olmuş, ancak ardından teflonun yerine kullandığı polietilen, 'düşük sürtünmeli artroplasti' olarak tanımlanarak tarihi sayılabilecek bir başarı kazanmıştır. İlk tasarım özellikleri olan $22 \mathrm{~mm}$ baş ile geleneksel polietilenin eklemleşmesi, 30 yılda yaklaşık \%87 sağkalım ile bugünün standartları için bile iyi sayılabilecek bir sonuca ulaşmaktadır. ${ }^{[1]} \mathrm{Bu}$ açıdan bakıldığında, doğru eklem yüzeyi tercihi yöntemin başarısını sağlayan anahtar olmuştur. Yöntemin daha da geliştirilmesi için, tasarım özellikleri yanı sıra yüzey seçenekleri üzerine de yoğun çalışmalar yapılmaktadır.
Implant technology evolved considerably since the first introduction of total hip replacement prosthesis at 1950's. Implant failure, aseptic loosening and prosthesis infection are the most common post-operative problems, and tribologic science developed to overcome these. Today different manufacturers produce a variety of implants, each having some pros and cons, and none of them proved superiority to others. These implants can be classified into two main groups in general: hard bearing implants and soft ones. Metal, oxinium and ceramic are the hard ones while polyethylene and derivatives consist the soft bearing group. Patients' physiological condition, expectations, activity level, primary pathology and the perference of the surgeon determine the surface selection.

Even today no bearing surface is the gold standard or considered as good for all patient groups. Thus, for arthroplasty surgeon, knowing the advantages and disadvantages of the materials is crucial.

Key words: total hip replacement; arthroplasty; surface properties; hip joint; polyethylenes; metals; ceramics; UHMWPE

Total kalça artroplastisinin, kullanılan malzemeler ve tasarım özellikleri ile ilişkilendirilebilecek en önemli sorunları arasında aseptik gevşeme ve çıkık sayılabilir. Aseptik gevşemenin aşınma partikülleri ile ilişkisi ortaya koyulduktan sonra, yüzey seçenekleri daha da önemli bir araştırma konusu haline gelmiştir. Çıkık riski ile kullanılan baş büyüklüğü arasındaki ters orantının gösterilmesi ile de, 22 mm'den büyük ve mümkün olduğu kadar az aşınma gösteren bir eklem yüzeyi idealize edilerek bu yönde çalışmalar yapılmıştır. ${ }^{[2]}$

Günümüzde geleneksel polietilen ve metal baş yerine kullanılan alternatifler temel olarak iki grupta incelenebilir. Birincisi, daha düşük aşınmaya sahip polietilen eklemleri (sert-yumuşak) içerirken bunun dışında kalan diğer grup ise her iki yüzeyin de sert materyallerden (sert-sert) oluştuğu eklemleri içerir.

- Illetişim adresi: Dr. Hakan Kocaoğlu, Ankara Üniversitesi Tıp Fakültesi, İbn-i Sina Hastanesi, 06100, Sıhhiye, Ankara Tel: 0312 - 5082321 Faks: 0312 - 3112522 e-posta: hkn.kocaoglu@gmail.com

- Gelis tarihi: 27 Mart 2013 Kabul tarihi: 12 Haziran 2013 


\section{SERT-YUMUŞAK EKLEMLEŞMELER}

\section{Ultra-yüksek moleküler ağırıklı polietilen/metal eşleşmesi}

Ultra-yüksek moleküler ağılıklı polietilen (ultra-high molecular weight polyethylene, UHMWPE) 2-6 mol moleküler ağırlığa sahip uzun polimer zincirlerine birleşik kristallerden oluşmuş bir yapıdır. ${ }^{[2]}$ UHMWPE, total kalça protezinin ilk günlerinden beri kullanılan bir yüzey malzemesi olmuştur. ${ }^{[3]}$ Son 30 yılda 4 milyondan fazla insana UHMWPE yüzeyi olan total kalça protezi yerleştirildiği düşünülmektedir. ${ }^{[4,5]}$ Uzun dönemli takip sonuçlarının iyi olması nedeniyle geleneksel UHMWPEmetal eşleşmesi, yeni eklemleşmelerin etkinliğini ve sağkalımını karşılaştırmak için kullanılan bir standart haline gelmiştir. ${ }^{[6]}$ UHMWPE kullanılarak çok daha ince asetabuler bileşenler üretilebilmektedir. Bu sayede orijinal femur başına çok daha yakın büyüklüklerde başlar kullanılabilmekte ve normal anatomi ve fonksiyona yakın sonuçlar elde edilebilmektedir (Şekil 1).[6] Büyüyen baş çapı sayesinde daha yüksek kalça hareket açıklığı ve daha düşük çıkık olasılığı izlenmektedir (Tablo 1). ${ }^{[1,2]}$

$\mathrm{Bu}$ güvenilir kullanım geçmişine karşılık, geriye dönük çalışmalar sonrasında UHMWPE'nin sert bir yüzeyle eklemleşmesi ardından $0,1 \mathrm{~mm} / \mathrm{yl}$ kadar kütle kaybına uğrayabildiği bilinmektedir. ${ }^{[2]} \mathrm{Her}$ ne kadar osteoliz, cerrahi teknik, implant tasarımı, hasta ve kullanılan malzemeye ait özelliklere bağlı çok etkenli bir olay olsa da, geleneksel UHMWPE'den oluşturulan debris miktarı metal-PE eşleşmesinin sağkalımını kısıtlayan en önemli etkendir. ${ }^{[7]}$ 2,5-4 Mrad gama ışını ile oksijenli ortamda sterilizasyonu sonucunda UHMWPE'nde oksidatif dejenerasyon görüldüğü ve bu durumun da materyalin yıpranma hızında artış, delaminasyon ve kırılmalara yol açtı̆̆ı
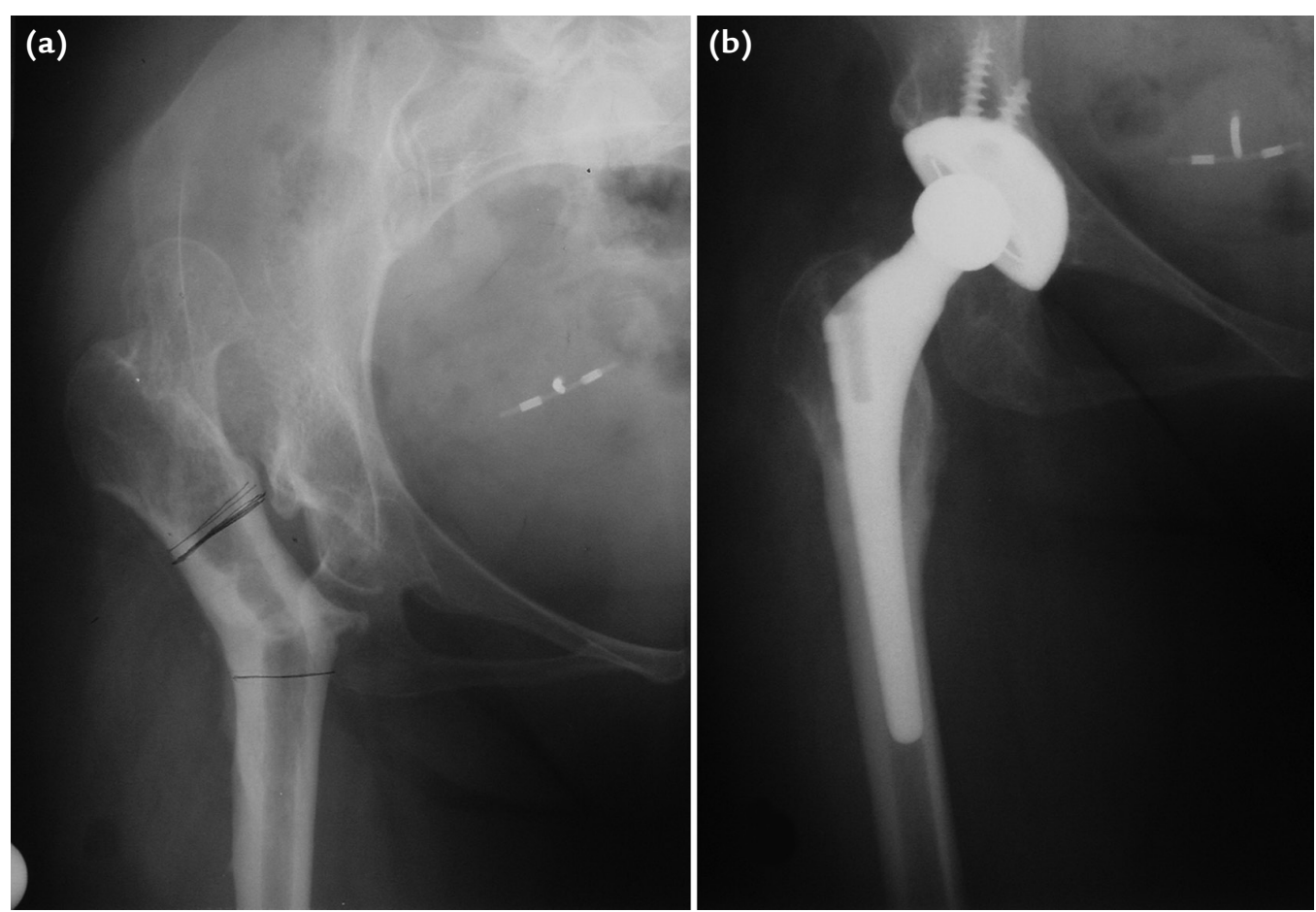

Şekil 1. Kırk yaşında, kadın hasta. Bilateral gelişimsel kalça çıkı̆̆ı nedeniyle bilateral şanz osteotomisi mevcut. Geleneksel polietilen ve metal baş $(\varnothing=22 \mathrm{~mm})$ ile total kalça artroplastisi yapılmış. Cerrahi öncesi yüksek yerleşimli femur başı, osteotomiye ikincil daralmış ve valgusta femoral kanal ve dar asetabulum gözüküyor (a). Cerrahiden 13 yıl sonra kontrol grafisinde gevşeme veya polietilen aşınması izlenmiyor. Normale yakın kalça eklem hareket açıklığı ve uzun süreli sağkalım sayesinde hastanın aktif şikâyeti bulunmamaktadır (b).

Tablo 1. Baş çapı ve kalça hareket açıklığı (ROM) ilişkisi (Passutti ve ark.). ${ }^{[3]}$

\begin{tabular}{lccccc}
\hline Baş çapı & $22 \mathrm{~mm}$ & $28 \mathrm{~mm}$ & $32 \mathrm{~mm}$ & $36 \mathrm{~mm}$ & $40 \mathrm{~mm}$ \\
\hline Hareket açıklı̆̆ı & $112^{\circ}$ & $127^{\circ}$ & $128^{\circ}$ & $132^{\circ}$ & $133^{\circ}$
\end{tabular}


fark edilmiştir. ${ }^{[4]}$ Devane ve Horne, çalışmalarında PE yıpranmasını etkileyen faktörleri; yaş, aktivite düzeyi, baş çapı, tespit yöntemi, PE kalınlığı ve ofsetin korunma miktarı olarak belirlemişlerdir (Tablo 2). ${ }^{[8]}$

Bu durum sektörü yeni materyaller ve yeni üretim teknikleri arayışına itmiştir. Üreticiler etilen oksit ve plazma gibi gama radyasyonundan başka yöntemlerle ya da vakum altında, asal gazlar veya oksijen bağlayıcıları varlığında radyasyon ile sterilizasyon yöntemleri geliştirmişlerdir. ${ }^{[4]}$

\section{Çapraz bağları arttırılmış ultra-yüksek moleküler ağırlıklı polietilen/metal eşleşmesi}

Total kalça protezinde sağkalımı arttırma ve yıpranmayı azaltma çabaları, araştırmacıları endüstriyel kullanımdan ilham alarak polietilendeki çapraz bağlanma oranını arttırmaya yöneltmiştir. Peroksit ile çapraz bağlanması arttırılmış polietilenin aşınma direncinin yükseldiği endüstride bilinmektedir. ${ }^{[9]}$ Tıbbi kullanım amacıyla da benzer biçimde kimyasal olarak çapraz bağları arttırılmış UHMWPE üretim yöntemleri tanımlanmıştır. 1998 yılından beri, kimyasal yönteme ek olarak, değişik üreticiler tarafından da radyasyon ve elektron ışıma yardımıyla çapraz bağlanmanın arttırılmasına yönelik işlemler tıbbi kullanıma sunulmuştur. ${ }^{[3]}$ Polietilen, sterilizasyon amacıyla kullanılan 2-4 MRad'dan çok daha yüksek dozlarda radyasyona veya elektron yağmuruna maruz kaldığında, zincir üzerindeki karbon-karbon bağlar kırılarak diğer zincirler ile çapraz bağlar oluşturur. Ancak, bu işlem sırasında istenmeyen yan ürünler olan okside moleküller, serbest radikaller ve ana zincir üzerinde kırılmalar (scission) oluşmaktadır. ${ }^{[10]}$ Bu yan ürünler, özellikle oksijen varlığında, polietilen üzerinde dejeneratif değişiklikler oluşmasına ve molekülün yıpranma direncinin düşmesine neden olurlar. Oksidasyon sürecini engellemek amacıyla, polietilenin üretim aşamalarında ek işlem basamakları ile, oluşan serbest radikaller azaltılır veya ortadan kaldırılırlar. Bu basamaklar, hammaddenin işlenmesi sırasında bir antioksidan olan vitamin E katkısı, radyasyon ile çapraz bağlanma sonrasında ısıl işlem ile eritme ve tavlama yapılması şeklinde olabilir. ${ }^{[5,11]}$

UHMWPE'nin bu işlemlere maruz bırakılması sonucunda yıpranmaya karşı direnci belirgin şekilde artış göstermektedir. Mc Kellop ve ark..$^{[5]}$ hem kimyasal olarak hem de ışılama ile çapraz bağları arttırılmış UHMWPE'leri geleneksel polietilenler ile karşılaştırdıkları in-vitro çalışmalarında geleneksel UHMWPE'lerle kıyaslandığında kimyasal işleme maruz kalanlarda \%93, radyasyona maruz kalanlarda \%87'ye kadar yıpranmada azalma izlemişlerdir. Muratoğlu ve arkadaşlarının ${ }^{[3]}$ revizyon geçirmiş hastalardan çıkartılmış asetabuler ara parçalar üzerinde yaptıkları ex-vivo çalışmalarda, 2,5 milyon adımlık döngüler sonrasında çapraz bağlı ara parçalarda ağırlık kaybı ve yüzey yıpranması izlenmemişken, geleneksel ara parçalarda 21,4-29,8 mg kadar kayıp ve yüzeyde aşınmaya bağlı değişiklikler gözlemişlerdir. In-vivo yapılan çift-kör prospektif randomize çalışmalar ve meta analizlerde de in-vitro ve ex-vivo çalışmalara benzer sonuçlar kaydedilmiştir. ${ }^{[7,11,12]}$ Engh

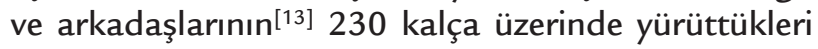
ileriye dönük çalışmada, aynı üreticiye ait çapraz bağlı ve geleneksel ara parçalar aynı asetabuler ve femoral komponentler kullanılarak karşılaştırılmıştır. Dört yıllık takip sonuçlarına göre, yıllık doğrusal yıpranma oranları çapraz bağlı UHMPWE'lerde $0,01 \pm 0,07 \mathrm{~mm} /$ yıl iken geleneksel UHMWPE'lerde $0,20 \pm 0,13 \mathrm{~mm} / \mathrm{yl}$ olarak ölçülmüştür. Benzer şekilde hacimsel yıpranma, çapraz bağlı polietilenlerde $5 \pm 22 \mathrm{~mm}^{3} /$ yıl, geleneksel polietilenlerde ise $107 \pm 76 \mathrm{~mm}^{3} / \mathrm{yl}$ düzeyinde kaydedilmiştir. Öte yandan çapraz bağlanma moleküle yıpranmaya karşı dayanıklılık sağlarken, materyalin plastisitesinde düşüşse neden olmaktadır. Holley ve arkadaşlarının ${ }^{[12]}$ çalışmaları sıkışma varlığını taklit eden modelde yıpranmanın arttığını ve kırılma direncinin düştüğünü göstermiştir. Kaydedilen değerler

Tablo 2. PE yıpranmasını etkileyen faktörler (Devane ve Horne). ${ }^{[8]}$

\begin{tabular}{lcc}
\hline Etken & Artmış yıpranma & Azalmış yıpranma \\
\hline Yaş & Genç $(<50$ yaş $)$ & Yaşıı \\
Aktivite düzeyi & Yüksek (2 milyon döngü/yıl $)$ & Düşük \\
Baş çapı & $32 \mathrm{~mm}$ & $26 / 28 \mathrm{~mm}$ \\
Fiksasyon & Makroporozite & Çimento \\
PE kalınlığı & $<8 \mathrm{~mm}$ & $>8 \mathrm{~mm}$ \\
Ofset & Korunmamış & Korunmuş
\end{tabular}



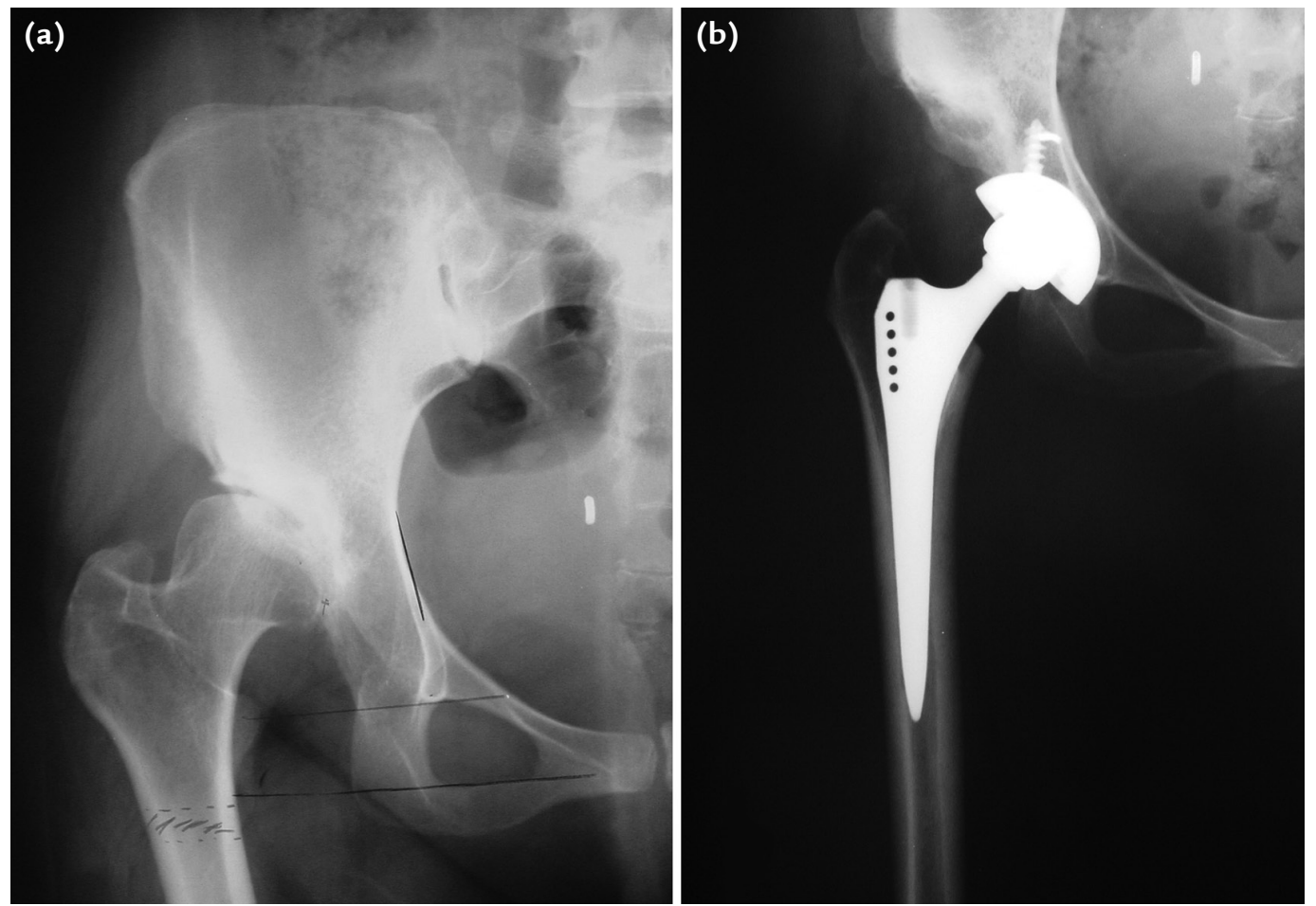

Şekil 2. Kırk üç yaşında, kadın hasta. Gelişimsel kalça çıkığı mevcut. Asetabulumun darlığı yüzünden ( $\varnothing=44 \mathrm{~mm})$ sadece polietilen iç parça seçeneği mevcut. Çapraz bağları arttırılmış polietilen ve metal baş ( $\varnothing=22 \mathrm{~mm}$ ) kullanılarak total kalça replasmanı yapılmış. Cerrahi öncesi yüksek yerleşimli femur başı ve dar asetabulum gözüküyor (a). Cerrahiden 7 yıl sonraki kontrol grafisi; gevşeme veya polietilen aşınması izlenmiyor. Hastanın da aktif şikayeti bulunmamaktadır (b).

sert-sert eklemleşmelerin dezavantajlarına benzer sonuçlar yansıtmaktadır. ${ }^{[12]}$

Yeni nesil yüzey seçenekleri ile karşılaştırıldığı zaman, partikül oluşumu ve osteoliz gibi riskleri taşısa da, UHMWPE-metal yüzeyler halen çok güvenilirdir ve birçok klinik duruma uyum gösterebilmektedir. Özellikle ileri yaşlarda ve düşük aktivite beklentisi olan hastalarda, gelişimsel kalça çıkığı veya travmatik artroz gibi asetabuler kap yerleşiminin istenilen yönelimi tam olarak karşılamadığı durumlarda ilk akla gelecek seçenektir (Şekil 2). Büyük baş çaplarına izin veren ara parçalar sayesinde de, düşük çıkık oranları bu eklemleşme için bir diğer tercih nedeni olacaktır.

\section{Ultra-yüksek moleküler ağırıklı polietilen/seramik eşleşmesi}

Metal-polietilen ve seramik-seramik eklemleşmenin var olan artılarını bir araya toplayıp istenmeyen özelliklerinden de kaçmak düşüncesi, UHMWPE-seramik çiftini doğurmuştur. Polietilen-metal çiftindeki yüksek debris miktarı ve osteoliz oranlarını ortadan kaldırmak amacıyla daha pürüzsüz bir yüzey sunan seramik seçilmiştir. Özellikle seramik-seramik çiftinde görülen çizgisel yıpranma, eklem hareketi ile oluşan sesler ve bileşen kırılmasından uzaklaşmak için sert-sert bir eşleşme yerine asetabuler yüzeyde polietilen kullanımı tercih edilmiştir.

Beaupre ve ark. ${ }^{[14]} 92$ hasta üzerinde yürüttükleri beş yıllık ileriye dönük çalışma sonucunda, seramikseramik ve seramik-çapraz bağlı UHMWPE çiftlere sahip hastaların eklem ağrısı, fonksiyon ve eklem sertliği açısından benzer sonuçlar gösterdiğini saptamışlardır. Bir başka ileriye dönükkarşılaştırma çalışmasında, seramik-seramik grubunda yıllık 30,5 $\mu \mathrm{m} /$ yıl yıpranmaya karşılık seramik-UHMWPE grubunda 218,2 $\mu \mathrm{m} /$ yıl yıpranma görülmüş olmasına rağmen, Harris Kalça Skoru ve SF-12 fiziksel ve ruhsal değerlendirmelerde bir fark görülmemiş ve gruplar arasında çıkık veya revizyon oranları arasında anlamlı fark oluşmamıştır. ${ }^{[15]}$

\section{Ultra-yüksek moleküler ağırlıklı polietilen/oksinyum eşleşmesi}

Oksitlenmiş zirkonyum-niyobyum alaşımının ısıya maruz bırakılması sonucu yüzeyde oluşan $10 \mu \mathrm{m}$ kalınlığındaki seramik-benzeri yüzey ile oksinyum hem metalik hem de seramik özellikler gösteren bir materyaldir. 

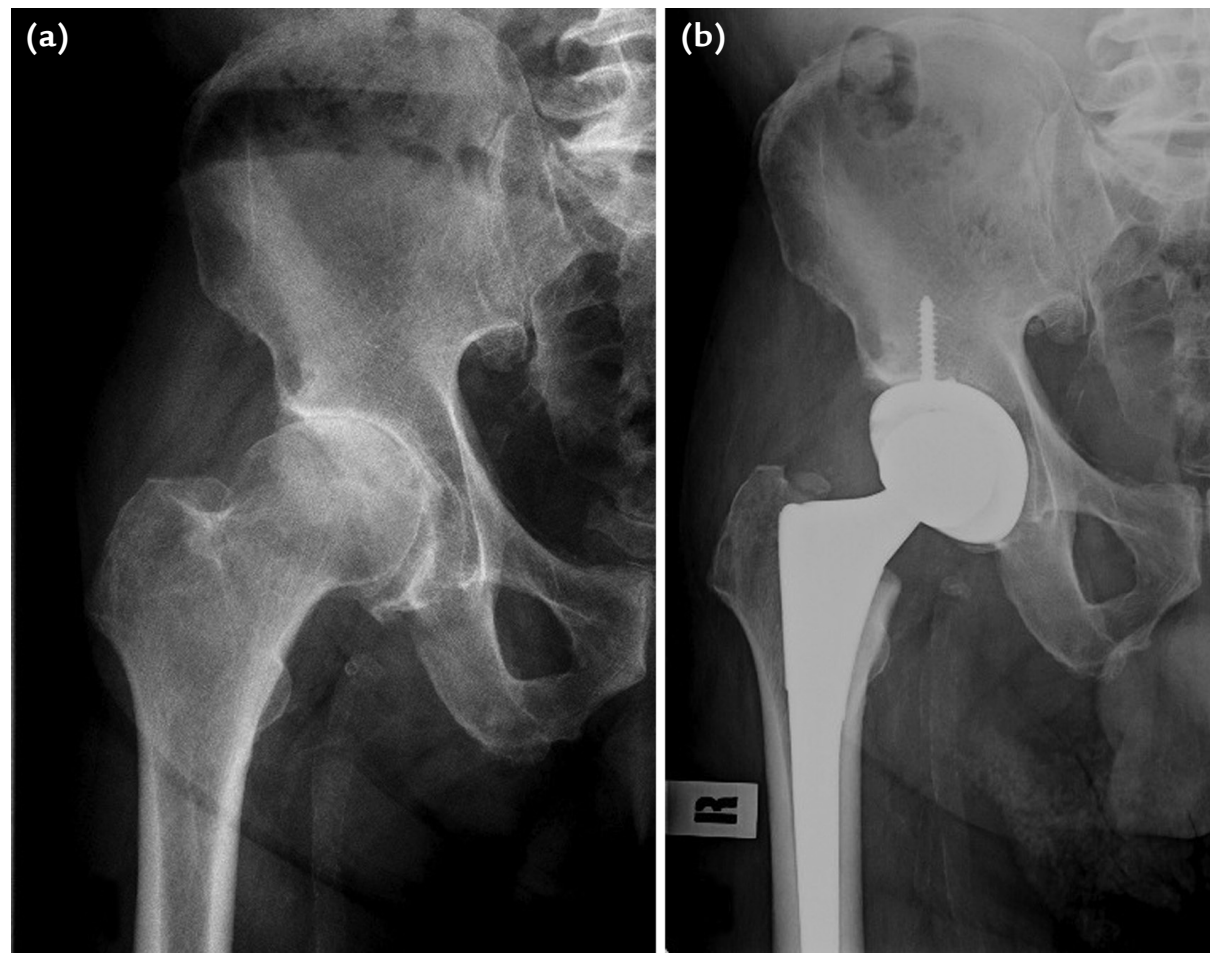

Şekil 3. Seksen yaşında, erkek hasta. Yaşam beklentisi 20 yıldan az olan ve orta derecede günlük aktiviteye sahip olan hastaya, çapraz bağları arttırılmış polietilen ve çıkık riskinden kaçınılmak amacıyla büyük çaplı oksinyum baş $(\varnothing=32 \mathrm{~mm})$ kullanılarak total kalça replasmanı yapılmış. Cerrahi öncesi sağ kalçada izlenen koksartroz (a). Çıkık riskinden kaçınmak amacıyla büyük çaplı femoral oksinyum baş tercih edilmiş (b).

[3] Kırılganlığı oldukça düşük olmakla beraber seramik yüzeyler gibi çok düşük yıpranma miktarlarına sahip olduğu in-vitro çalışmalar ile gösterilmiştir. ${ }^{[16,17]}$ Temel olarak bu çiftin özellikleri UHMWPE-seramik çiftler ile yakın benzerlik göstermektedir. Seramik-seramik eşleşmenin kullanılamadığı yaşlı veya yönelim sorunu yaşanabilecek hastalarda, tıpkı UHMWPE-seramik gibi, tercih edilebilecek bir çifttir. Ayrıca ince polietilen iç parça, büyük baş çapı kullanılmasına izin vermesi açısından önemlidir (Şekil 3).

\section{SERT-SERT EKLEMLEŞMELER}

\section{Metal-metal eşleşmesi}

ilk kuşak kobalt krom metal-metal eklem yüzeyleri 1960'larda ortaya çıkmış olup, onu 1980 'li yılların sonunda ikinci kuşak izlemiş̧tir. Bu ikinci kuşak yüzeylerin aşınma oranlarının geleneksel polietilene kıyasla 20-100 kat daha az olduğu bilinmektedir; ${ }^{[1]}$ iyileşen aşınma oranlarına ek olarak metal eklem yüzü ile polietilen gibi bir ara maddeye ihtiyaç duyulmaması sonucu, daha ince bir asetabuler komponent ve daha büyük başların kullanımına imkân vermektedir. Artan baş çapı, özellikle genç ve aktif hasta grubunda, eklem hareket açıklığının son noktalarında sıkışmayı azaltarak çıkık oranlarını düşürmektedir.

Biyomekanik avantajlarına karşın metal/metal yüzeyin temel sorunu, aşınma sonucu ortaya çıkan metal iyonlarının vücut içerisinde yaygın dağılımı ve yol açtığı tepkimedir. Daha çok eklem çevresinde biriken ve lokal olarak osteolize sebep olan polietilenin aksine, metal iyonları tüm vücutta dağılım gösterir. Özellikle implantın yerleştirildiği ilk 1-2 yıllık sürede gözlenen hızlı aşınma döneminde, takip eden durağan döneme kıyasla 5 kata kadar daha fazla partikül salınmaktadır. ${ }^{[6]} \mathrm{Bu}$ iyonlar kan-beyin bariyeri gibi engelleri de geçerek santral sinir sistemi ile tüm iç organlarda birikim gösterir. Gebelikte ise plansental bariyeri geçerek fetüste birikim gösterdiği bilinmektedir. Metal-metal eklemli total kalça artroplastisi uygulanan birkaç hastada doğum gerçekleşmiş olup, morfolojik bir anormallik tespit edilmemiş olmakla beraber, bu durumun uzun dönem etkileri konusunda kesin bir bilimsel veri bulunmamaktadır. ${ }^{[18]}$ Bu nedenle, bu eklem yüzeyinin doğurganlık çağındaki kadınlar için tercih edilmemesi gerektiği yönünde genel bir kabul vardır. 
Metal iyonları biyolojik olarak polietilen partiküllerinden daha etkindir ve zaman zaman eklem çevresinde abartılı bir lenfositik tepkimeye sebep olabilir. Bunun yanı sıra toplumda $\% 5$ kadar görülebilen nikel alerjisi de metal iyonlarına karşı bir hassasiyet işareti olarak değerlendirilebilir. ${ }^{[1]} \mathrm{Her}$ ne kadar metal-metal eklem yüzü tercihi için ameliyat öncesi bir cilt testinin işe yaradığı gösterilmemiş olsa da, hastanın özellikle metal eşya ve takılara karşı cilt tepkimesi gösterip göstermediği sorgulanmalıdır.

\section{Seramik-seramik eşleşmesi}

Düşük sürtünme katsayıları, yüksek aşınma direnci ve biyouyumluluk kapasitesi ile okside edilmiş metal olarak tanımlanabilecek seramik, ideal bir eklem yüzü olarak görülmüştür. Ancak erken dönem seramik-seramik eklemleşmesi, yetersiz kilitlenme gibi tasarım sorunlarına ek olarak üretim problemleri nedeni ile yüksek kırık oranlarına yol açmıştır. Tasarım ve üretim sorunları giderildikten sonra, 1994 yılından itibaren geliştirilen ve halen kullanılan üçüncü kuşak seramiklerde kırık oranlarının genel olarak \%0,5'ten az olduğu bildirilmektedir. [19] Benzer şekilde, 500.000 seramik femur başını inceleyen bir gözden geçirmede, kırık oranı yüzbinde 4 oranında verilmiştir ki, aynı seride femoral komponent kırığı elli kat fazla tespit edilmiştir. ${ }^{[20]} \mathrm{Bu}$ açıdan bakıldığında uygun açıda yerleştirilmiş bir asetabuler komponent ile seramik eklem yüzünde kırık endişesi en az olmalıdır.

Her ne kadar nadir görülse de, seramik kırığı kalça revizyon girişimi için önemli bir sorun oluşturmaktadır. Zira seramik partikülleri, revizyonda kullanılan yüzeylerde üçüncü bir cisim olarak ciddi aşınmaya neden olabilmektedir. Bu nedenle seramik kırığı nedeniyle yapılan revizyon girişimlerinde, erken müdahale ile parçacıkların yayılması ve ufalanmasının önüne geçilmesi ile, yaygın bir sinoviyektomi yapılarak gözle görülmeyen parçacıkların da çıkartılması büyük önem taşımaktadır.

Yürüme sırasında kalça ekleminden ses çıkması da nadir görülen $(\sim 0,05)$ bir sorundur. Bu durumda nadiren revizyon girişimine gerek duyulmakla beraber, hasta için oldukça önemli bir sorun oluşabilmektedir. Etiyolojisi kesin olmamakla birlikte, daha çok ideal asetabuler komponent abduksiyon açısı olarak kabul edilen $45^{\circ} \pm 10^{\circ}$ dışında yer alan hastalarda görüldügüu bilinmektedir. ${ }^{[21]} \mathrm{Bu}$ sesin kenar yüklenmesi ile ilişkili olduğu öne sürülmektedir ama seramik kırığının erken bir bulgusu olduğuna dair herhangi bir veri bulunmamaktadır.

Sonuç olarak modern seramik-seramik eklem yüzeyleri, yaşam beklentisi yüksek ve temas sporu yapmayan hasta grubunda güvenle tercih edilebilir (Şekil 4, 5, 6).
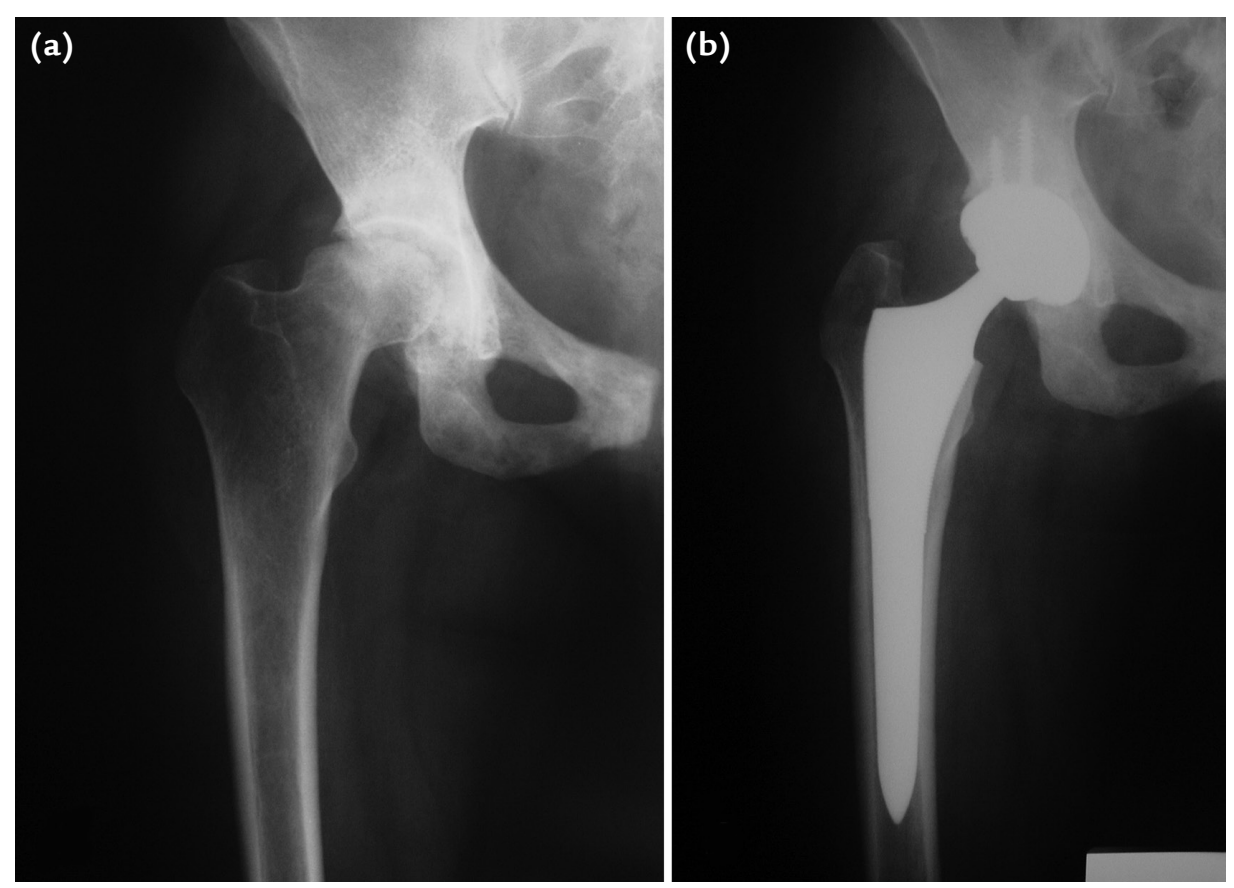

Şekil 4. Yirmi sekiz yaşında, kadın hasta. Femur başı avasküler nekrozuna sekonder koksartroz nedeniyle genç yaşta eklem replasmanına ihtiyaç duyan hastaya seramik iç parça ve seramik baş ( $\varnothing=28 \mathrm{~mm}$ ) eşleşmesi ile total kalça artroplastisi yapılmış. Sağ kalçada femur başı avasküler nekrozuna ikincil koksartroz (a). Seramik-seramik eklemleşme ile uzun sağkalım amaçlanarak yapılmış total kalça artroplastisi (b). 

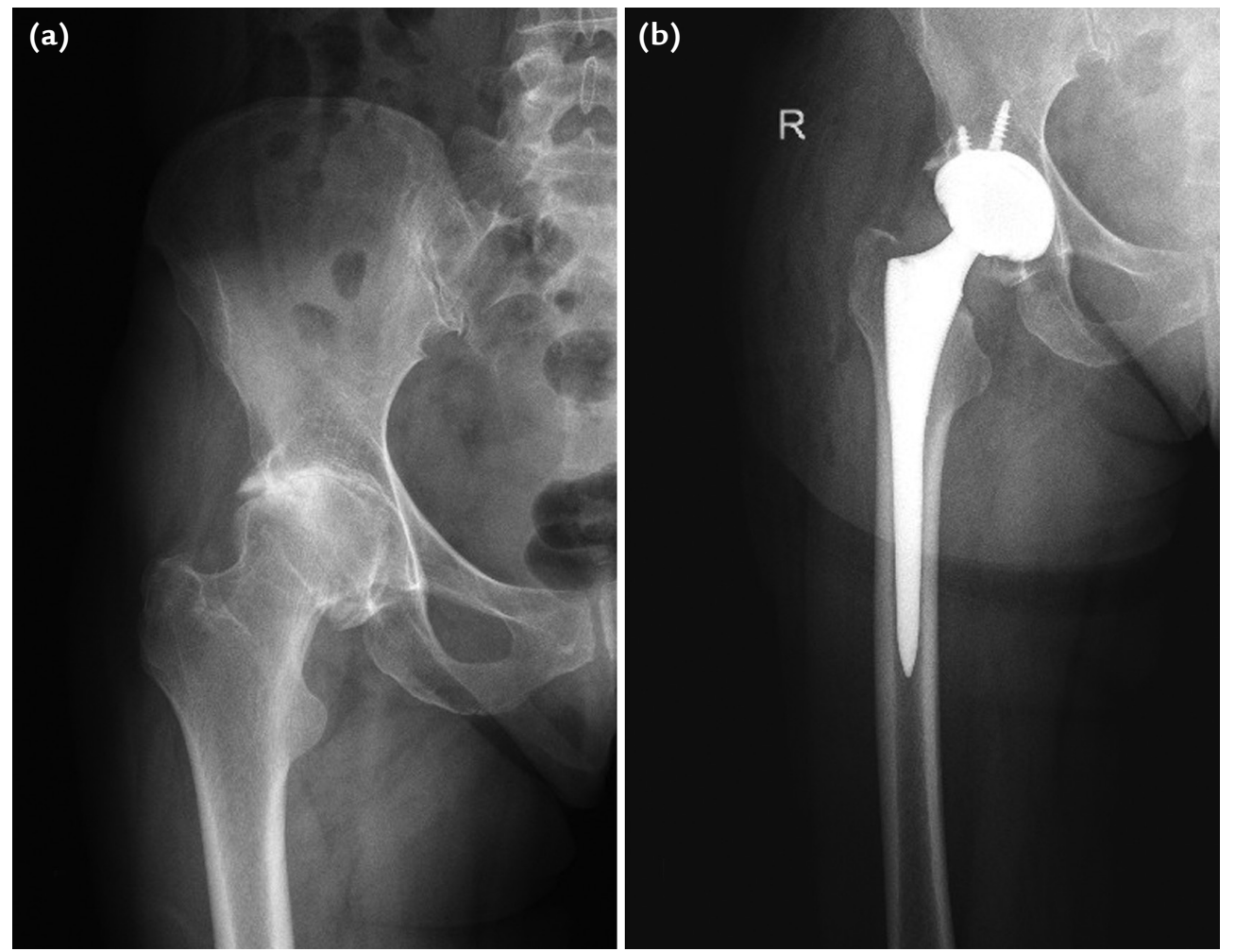

Şekil 5. Elli yaşında, kadın hasta. Romatoid artrit tutulumuna ikincil koksartroz. Hastanın uzun yaşam beklentisi ve aktif bir hayatı olması nedeniyle seramik iç parça ve seramik baş ( $\varnothing=36 \mathrm{~mm})$ total kalça artroplastisi yapılmış. Sağ kalçada romatoid artritte ikincil koksartroz (a). Aktif günlük aktiviteleri karşılamak için seramik/seramik eklemleşme tercih edilmiş (b).
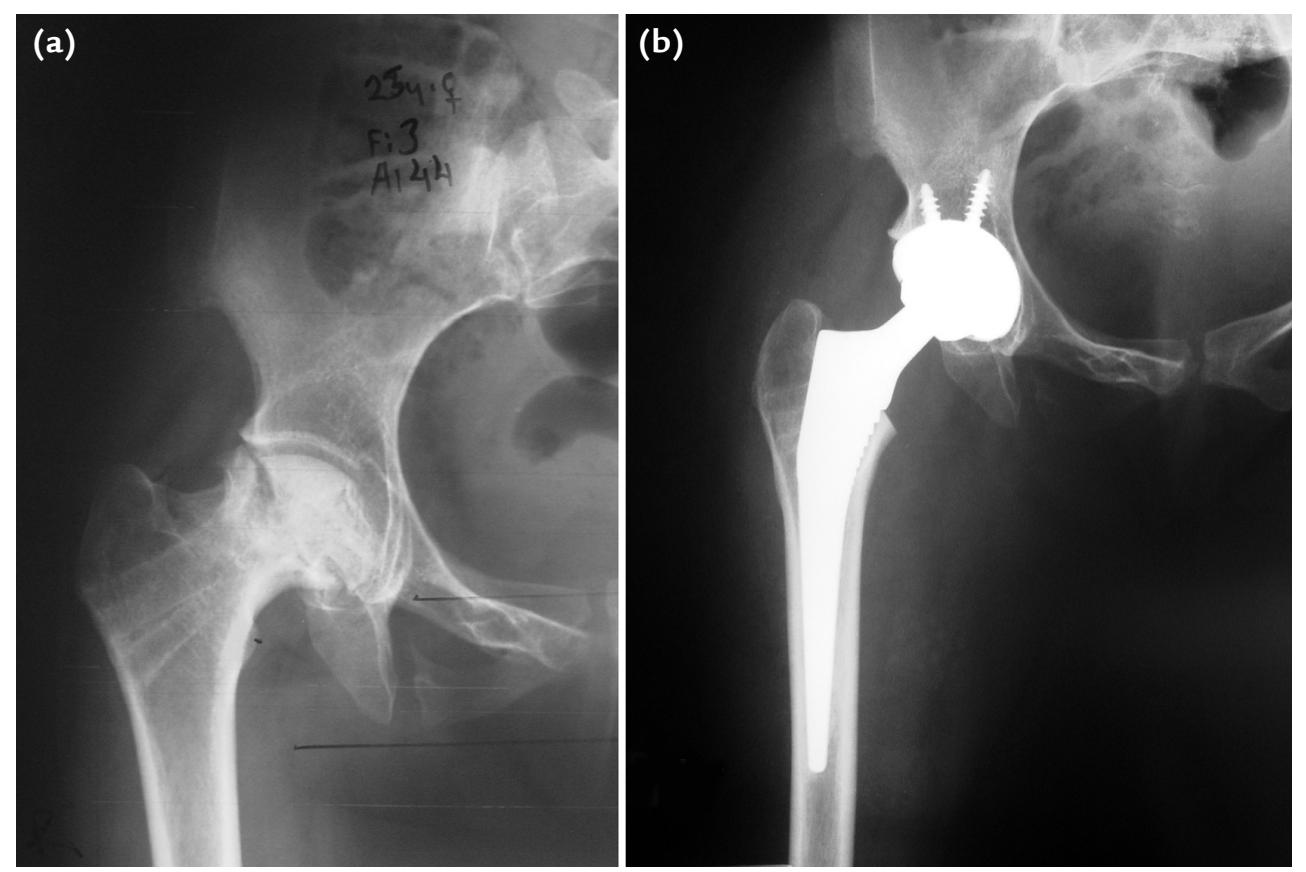

Şekil 6. Yirmi beş yaşında, kadın hasta. Sekonder koksartroz nedeniyle genç yaşta eklem replasmanına ihtiyaç duyan hastaya seramik iç parça ve seramik baş $(\varnothing=28 \mathrm{~mm})$ eşleşmesi ile total kalça artroplastisi yapılmış. Sağ koksartroz (a). Seramik-seramik eklemleşme ile uzun sağkalım amaçlanarak yapılmış total kalça artroplastisi (b). 

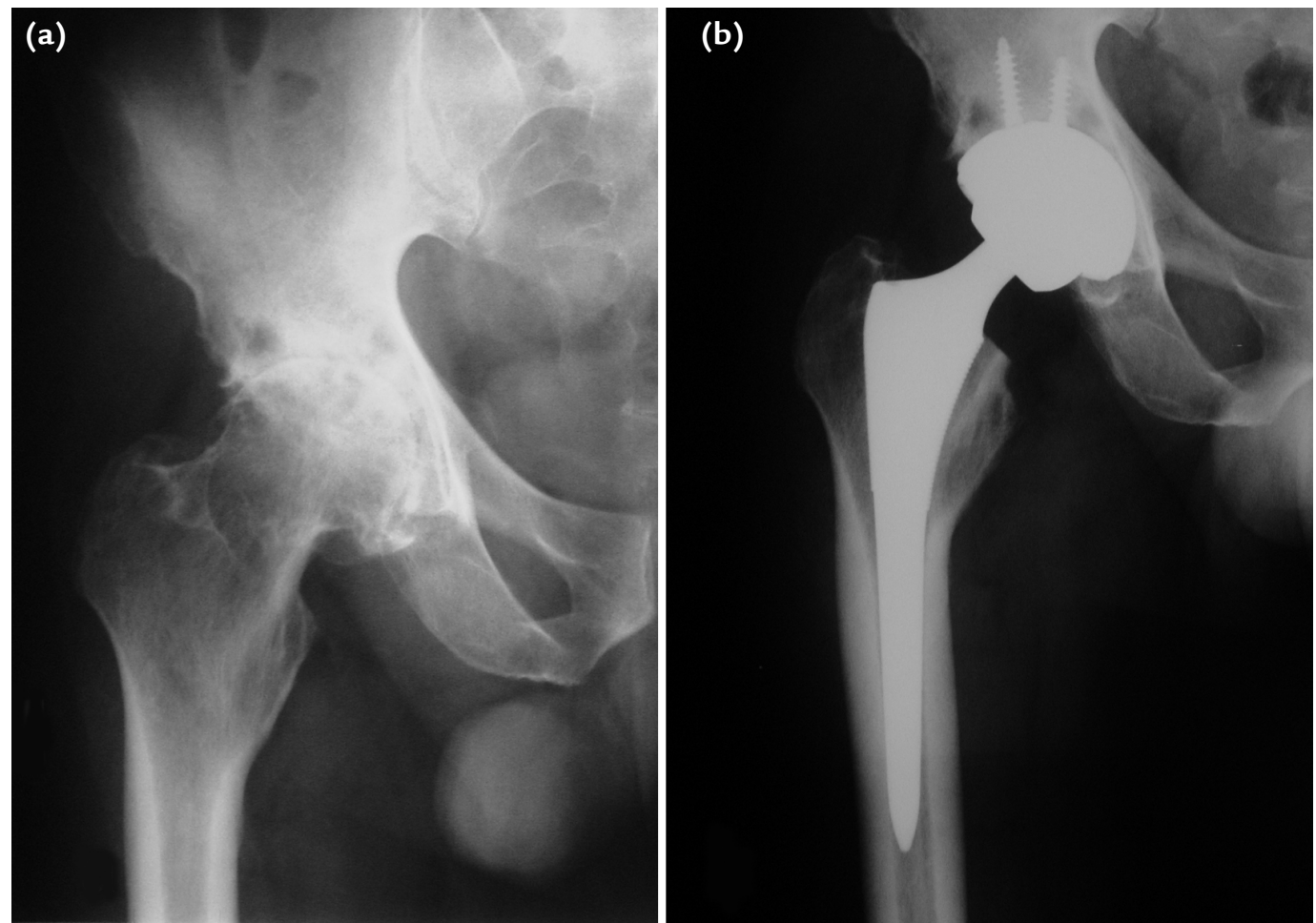

Şekil 7. Elli beş yaşında, erkek hasta. Halen aktif olarak ağır işte çalışan hastaya uzun sağ kalım amacıyla seramik iç parça ve metal baş $(\varnothing=36 \mathrm{~mm})$ eklemleşme tercih edilmiş. Sağ koksartroz (a). Seramik-metal çifti ile yapılmış total kalça artroplastisi, hastanın ağır çalışma koşullarına karşınherhangi bir komplikasyon veya gıcırdama benzeri rahatsızlık yaratmamaktadır (b).

\section{Seramik-metal eşleşmesi}

Bu eklem yüzeyi, metal parçacıklarından ve seramik kırık riskinden kaçınarak her iki (sert-sert) yüzeyin ideal yönlerini birleştirmek amacı ile ortaya konulmuştur. Mevcut literatürde başarılı sonuçlar bildiren çalışmalar olmakla birlikte, metal-metal ve seramik-seramik yüzeylerin aksine, bu konuda yapılmış herhangi bir randomize çalışma bulunmamaktadır. ${ }^{[19]}$ Metal eklem yüzeyinin kaçınılması gerekli problemlerinden birisi olan metal iyon düzeyleri, seramik-metal eklemleşmesinde belirgin derecede daha düşük düzeylerde gerçekleşmektedir. Isaac ve ark. ${ }^{[22]}$ implantasyondan bir yıl kadar sonra yaptıkları iyon düzeyi ölçümlerinde, değerlerin ameliyat öncesi düzeylere kadar gerilediğini tespit etmişlerdir. Buna ek olarak 2011 yılına kadar yerleştirilmiş olan yaklaşık 10.000 kadar seramik metal kalça artroplastisinde, herhangi bir ses çıkartma veya gıcırtı komplikasyonu bildirilmemiştir (Şekil 7). [23]

Günümüzde en başarılı cerrahi girişimler arasında üst sıralarda yer alan total kalça protezlerinin uzun sağkalım süresini etkileyen faktörlerin başında doğru endikasyon ve mükemmel cerrahi teknik gelmekle birlikte, hastanın yaşı ve aktivite düzeyi bakımından ideal eklemleşmenin hangisi olduğuna, bir başka deyişle "kime, hangi ikili?" sorusuna doğru cevap verebilmek gelmektedir. Genç ve aktif yaş grubunda, total kalça protezi sonrası hastanın beklentisi fazladır. Hasta ameliyat sonrası ağrısız, fonksiyonel bir kalça eklemine sahip olmak ister ve haklı olarak da cerrahtan uzun süre dayanabilecek bir protez konmasını bekler. Bu noktada genç ve aktif yaş grubunu tanımlamak gerekir. Altmış beş yaş ve altı popülasyon, ülkemizde sosyal güvenlik kurumu açısından da genç ve aktif yaş grubu olarak kabul edilmiştir. Aşınmaya karşı en dirençli ikili seçeneği olan seramik-seramik, 65 yaş ve altı hastalarda uygulandığı takdirde güvenlik kurumu tarafindan ödenmektedir. ${ }^{[24]}$ Ancak seramik-seramik seçeneğini sadece yaşa bağlı olarak seçmemek gerekir. Bilindiği üzere ülkemizde gelişimsel kalça displazisi ve/ veya çıkığına ikincil gelişen osteoartritler sıktır. Özellikle Crowe Tip 3 ve 4 kalçalarda gerçek asetabulum çok küçük olup, genellikle 38-42 mm büyüklügün̈de kaplar kullanılmakta, ancak bu boylarda seramik seçeneği bulunmamaktadır. Bu boylarda polietilen kalınlığı açısından $22 \mathrm{~mm}$ baş kullanılmakta; bu da çıkık riskini arttırmaktadır. Gene displazik kalçalarda, her zaman olmamakla birlikte, bazen kemik örtünme miktarını arttırmak için asetabuler komponent ideal abduksiyon ve 
anteversiyon açıları üst limitlerde olacak şekilde koyulabilmektedir. Böyle yerleştirilmiş bir kapta, seramik hatta metal yüzey tercihi kanımızca kesinlikle yanlıştır. Çünkü aşıı kenar yüklenmesi aşınmayı tetikleyecektir. Bu vakalarda iyileştirilmiş polietilen ile seramik ya da oksinyum baş seçilmelidir. Genç ve aktif yaş grubunda hareket açıklı̆̆ı beklentisi fazla olduğu için, baş 32 ya da $36 \mathrm{~mm}$ olarak tercih edilmelidir. Metal-metal seçeneği, özelikle doğurganlık çağında olan ya da böbrek problemi veya metal allerjisi bulunan hastalarda kullanılmamalıdır. Gene ağır aktivitesi olan ya da aktif spor hayatı olan hastalarda metal-metal seçeneği doğru yaklaşım olmakla birlikte aseptik lenfositik vaskülitle birlikte olan lezyon (aseptic lymphocyte-dominated vasculitis-associated lesion - ALVAL) tepkimeye yol açabileceği düşünülmelidir. Yaşları 65-80 aralığında olan hastalarda iyileştirilmiş polietilen ve seramik ya da metal baş, çıkık riskini azaltmak için de mümkünse $32 \mathrm{~mm}$ baş seçeneği tercih edilmelidir. Seksen yaş üstü hastalarda ise geleneksel polietilen ve $32 \mathrm{~mm}$ metal baş en uygun ikilidir. Görüldüğü üzere ideal eklemleşme her hasta açısından farklılık gösterebilmektedir. Bu nedenle total kalça protezi uygulanması düşünülen hastalarda seçilecek eklemleşme ile ilgili olası avantaj ve dezavantajların ayrıntılı olarak bilinmesi büyük önem taşımaktadır.

\section{KAYNAKLAR}

1. Tailor H, Patel S, Patel RV, Haddad FS. Bearing couples in total hip arthroplasty. Br J Hosp Med (Lond) 2010;71(8):446-50.

2. Passuti N, Philippeau JM, Gouin F. Friction couples in total hip replacement. Orthop Traumotol Surg Res 2009;95(4 Suppl 1);S27-34. CrossRef

3. Muratoglu OK, Wannomae K, Christensen S, Rubash HE, Harris WH. Ex vivo wear of conventional and cross-linked polyethylene acetabular liners. Clin Orthop Relat Res 2005;438:158-64.

4. Campbell P, Shen FW, McKellop H. Biologic and tribologic considerations of alternative bearing surfaces. Clin Orthop Relat Res 2004;(418):98-111.

5. McKellop H, Shen FW, Lu B, Campbell P, Salovey R. Development of an extremely wear-resistant ultra high molecular weight polyethylene for total hip replacements. J Orthop Res 1999;17(2):157-67.

6. Manley MT, Sutton K. Bearings of the future for total hip arthroplasty. J Arthroplasty 2008;23(7 Suppl):47-50. CrossRef

7. Kuzyk PR, Saccone M, Sprague S, Simunovic N, Bhandari M, Schemitsch EH. Cross-linked versus conventional polyethylene for total hip replacement: a meta-analysis of randomised controlled trials. J Bone Joint Surg Br 2011;93(5):593-600. CrossRef

8. Devane PA, Horne JG. Assessment of polyethylene wear in total hip replacement. Clin Orthop Relat Res 1999;(369):59-72.

9. Himont Tech Info, Bulletin HPE-116: 1900 ultrahigh molecular weight polymer: effect of polymer modification. USA: Wilmington, Himont; 1987.
10. McKellop HA. Bearing surfaces in total hip replacements: state of the art and future developments. Instr Course Lect 2001;50:165-79.

11. Oral E, Muratoglu OK. Vitamin E diffused, highly crosslinked UHMWPE: a review. Int Orthop 2011;35(2):215-23. CrossRef

12. Holley KG, Furman BD, Babalola OM, Lipman JD, Padgett DE, Wright TM. Impingement of acetabular cups in a hip simulator: comparison of highly cross-linked and conventional polyethylene. J Arthroplasty 2005;20(7 Suppl 3):77-86.

13. Engh Jr CA, Stepniewski AS, Ginn SD, Beykirch Se, SycterzTerefenko CJ, Hopper Jr RH, Engh CA. A randomized prospective evaluation of outcomes after total hip arthroplasty using cross-linked marathon and non-crosslinked Enduron polyethylene liners. J Arthroplasty 2006;21(6 Suppl 2):17-25.

14. Beaupre LA, Manolescu A, Johnston DW. A randomized trial of ceramic-on-ceramic bearing versus ceramic-on-crossfirepolyethylene bearing in total hip arthroplasty: five-year outcomes. J Arthroplasty 2013;28(3):485-9. CrossRef

15. Amanatullah DF, Landa J, Strauss EJ, Garino JP, Kim SH, Di Cesare PE. Comparison of surgical outcomes and implant wear between ceramic-ceramic and ceramic-polyethylene articulations in total hip arthroplasty. J Arthroplasty 2011;26(6 Suppl):72-7. CrossRef

16. Good V, Ries M, Barrack RL, Widding K, Hunter G, Heuer D. Reduced wear with oxidized zirconium femoral heads. J Bone Joint Surg Am 2003;85-A Suppl 4:105-10.

17. Kadar T, Hallan G, Aamodt A, Indrekvam K, Badawy M, Skredderstuen A, Havelin LI, Stokke T, Haugan K, Espehaug $B$, Furnes $O$. Wear and migration of highly cross-linked and conventional cemented polyethylene cups with cobalt chrome or Oxinium femoral heads: a randomized radiostereometric study of 150 patients. J Orthop Res 2011;29(8):1222-9. CrossRef

18. deSouza RM, Wallace D, Costa ML, Krikler SJ. Transplacental passage of metal ions in women with hip resurfacing: no teratogenic effects observed. Hip Int 2012;22(1):96-9. CrossRef

19. Zywiel MG, Sayeed SA, Johnson AJ, Schmalzried TP, Mont MA. Survival of hard-on-hard bearings in total hip arthroplasty: a systematic review. Clin Orthop Relat Res 2011;469(6):153646. CrossRef

20. Willmann G. Ceramic femoral head retrieval data. Clin Orthop Relat Res 2000;(379):22-8.

21. Greene JW, Malkani AL, Kolisek FR, Jessup NM, Baker DL. Ceramic-on-ceramic total hip arthroplasty. J Arthroplasty 2009;24(6 Suppl):15-8. CrossRef

22. Isaac $G H$, Brockett $C$, Breckon A, Van Der Jagt D, Williams $S$, Hardaker C, Fisher J, Schepers A. Ceramic-on-metal bearings in total hip replacement: whole blood metal ion levels and analysis of retrieved components. J Bone Joint Surg Br 2009;91(9):1134-41. CrossRef

23. Cigada A, Cotogno G, Chiesa R. The ceramic-on-metal coupling in total hip replacements for young patients: a review study. J Appl Biomater Biomech 2011;9(1):2-10. CrossRef

24. Sosyal Güvenlik Kurumu Sağlık Uygulama Tebliği. Resmi Gazete: 25.03.2010/27532 (Mükerrer) Madde 7.3.16.

25. Erdemli B, Yılmaz C, Atalar H, Güzel B, Çetin I. Total hip arthroplasty in developmental high dislocation of the hip. J Arthroplasty 2005;20(8):1021-8. 